\title{
精揉機における液化石油ガスの使用試験
}

\section{Experimental Survey on the Utilization of Liquid Petroleum Gas in the Final Tea Roller}

\section{1 まえがき}

最近，製茶用然料として，液化石油前スの使用方心 光，各場所においても，ての試験を取りあげているとて ろが多いので，同一設計忙より試験を行い，なるべく早 くその使用法を磂立するそめ，昭和33年 2 月，九州農業 試験場において開催された打合せ会锇に执いて，共通試 験を行うことを決定した。よつててれ《従い下記 8 埸所

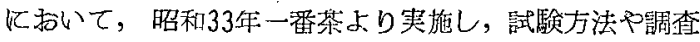
貿目に不備の点も市るが，一统所期の目的を達したので その成綪を報告する。

実笆した場所 埼玉県茶業研究所, 東海近畿農業試験

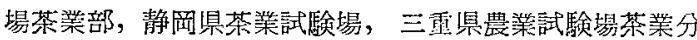

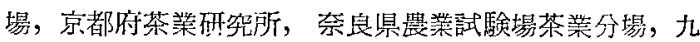
州㖘業試験場作物第一部, 鹿児島県茶業試験場。

\section{2 試 験 設 計}

\section{1 目 的}

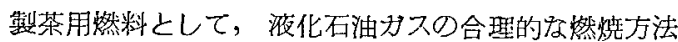

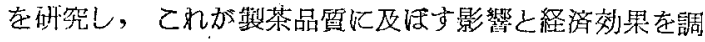
查する。

\section{2 方 法}

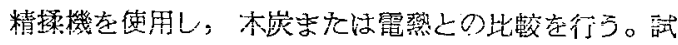

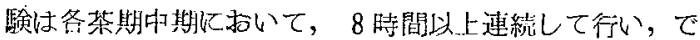

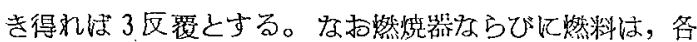
場所化扮いて適当と認められたものを供試し，夜化石油 カ3スのうち妿温を必要とするものについては，ボンベを 水槽汇入れて使用する。

\section{3 調查事 項}

(1) 火袋和よび燃烛器の構造

式名，性能を明記するととも飞構造を图示する。
(2) 温 度

（a）精揉機温暨 投入前伅揉艋の両側のみぞの最底 部中央に，棒状温度計を直角傜請して測定する。なお パイロメーターのあるとてろでは 同時にこれを用いて測 定声る。

（b）水槽の温度 1 時間括き飞棒状温度計飞より測 定し，室温もあ的せて記録する。

(3) 然料の消䩀量

8 時間連続の消費量から，時間当りと，製茶 $10 \mathrm{~kg}$ 当 りのるのを算出する。ただし予熱特間忏除外する。

(4) 荣の品買

普通謇查法による。

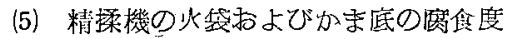
肉腿観察による。

\section{3 試 験 成 績}

\section{1 埼玉県茶業研究所}

(1) 試 験 区別

試験区別は第 1 表のと扮りである。

第1表 試 験 区 別

\begin{tabular}{|c|c|c|c|}
\hline 区 別 & 蜘 誻 器 & 然料 & 構 造 の概要 \\
\hline 第 1 区 & 従来の上柯り & 木炭 & \\
\hline 篛 2 区 & 狭【プロパン式 & ガス & 昭和!32年成績参照 \\
\hline $\begin{array}{l}\text { 第3区 } \\
\text {, }\end{array}$ & 東洋酸素式 & " & 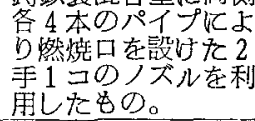 \\
\hline
\end{tabular}

(2) 撚料消费料

燃料の消費量䄱よびその鍂額などは，第 2 表に示した と路りで西る。

第 2 表 然料消 貲 量

\begin{tabular}{|c|c|c|c|c|c|c|c|c|c|c|c|}
\hline \multirow{2}{*}{ 区 別 } & & \multirow{2}{*}{ 铽験時間 } & \multicolumn{3}{|c|}{ 総 消 費 量 } & \multicolumn{3}{|c|}{1 愽間当 } & \multicolumn{3}{|c|}{ 茶 $10 \mathrm{~kg}$ 当り } \\
\hline & $1+1$ & & 蜘 料 & 金 額 & 比 率 & 燃 料 & 金 額 & 比率 & 然 料 & 金 額 & 比 率 \\
\hline 第 1 区 & 亦 & $\begin{array}{l}\min \\
480\end{array}$ & $\begin{array}{r}\mathrm{k} \varepsilon \\
4.475\end{array}$ & 151.00 & 100 & $\begin{array}{r}\mathbf{k} \\
0.572\end{array}$ & 18.87 & 100 & $\begin{array}{r}\mathrm{k} \\
0.972\end{array}$ & 32.00 & 100 \\
\hline 第2 2 区 & プロパンガフ & 480 & 2.093 & 167.44 & 111 & 0.262 & 20.96 & 111 & 0.364 & 29.12 & 91 \\
\hline 第3区 & プロパンガフ & 480 & 2.453 & 196.24 & 130 & 0.307 & 24.56 & 130 & 0.462 & 36.96 & 116 \\
\hline
\end{tabular}

㣁考：調查注一番茶期中に実施し，木炭は 5 回，狭山プロ パン，東洋酸素は12回の平均。 然料単洒は $\mathrm{kg}$ 当り木炭は33円，プロパンガズ 80 円とする。 
(3) 空内の温湿度挍よびボンベ水槽温度

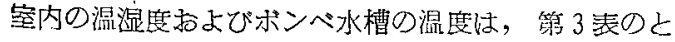
拾りである。

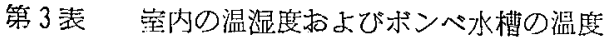

\begin{tabular}{|c|c|c|c|}
\hline 質 & 鼠 高 & 最 低 & 平 沟 \\
\hline 室 内 温 度 $\left({ }^{\circ} \mathrm{C}\right)$ & 28.7 & 22.0 & 27.9 \\
\hline$"$ 湿 度(\%) & 54.8 & 37.7 & 43.5 \\
\hline ボンべ水槽温度 $\left({ }^{\circ} \mathrm{C}\right)$ & 19.9 & 15.9 & 17.7 \\
\hline
\end{tabular}

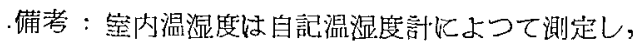
3 日間の平均值であり，ボンべ水槽温度は 6 日間の平均值である。

(4) 摘 要

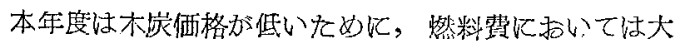
きな差はないが，然焼装置の視造いかんは相当の美が認 められるので，使用炕当つては，器具の選定が㻎要であ。 る。

\section{2 東海近畿農業試験場茶業部}

（1）方法和よび試駼区別

伊達式 4 手精揉機を 2 手ずつ飞 2 種のガスを，八木式 2 手比炭を用いて，各種の調查在行つだ。また，が 底の庽食度は，相当長㭙間の使用を要与ると思われたの で，生等家に委托して，4手精揉機にガスと㨏を 2 手 ずつ用いて調查した。

試験区別は笎 4 表の上括りである。

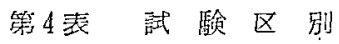

\begin{tabular}{|c|c|c|c|c|}
\hline$区$ & & 別 & 燃 烧 器 & 料 \\
\hline 第 & 1 & 区 & 従来のと莉り & 林炭 (雑弿) \\
\hline 第 & 2 & 区 & 犬井川ガス式 & イソブタンガス \\
\hline 第 & 3 & 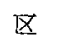 & 岩谷屡業式 & \\
\hline
\end{tabular}

（2）然料消費最すよび茶温

蜘料消費量とその金額，稿よび䒩温等は第 5 表に示し

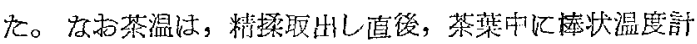
を埋めて測定した。

第 5 表然料消費量扣よび茶温

\begin{tabular}{|c|c|c|c|c|c|c|c|c|c|c|c|c|c|}
\hline \multirow{2}{*}{ 軺試月日 } & \multirow{2}{*}{ 区 別 } & \multirow{2}{*}{ 試験㭙間 } & \multirow{2}{*}{$\begin{array}{c}1 \text { 時間 } \\
\text { 晃 } D \\
\text { 製茶量 }\end{array}$} & \multirow{2}{*}{ 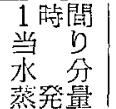 } & \multirow{2}{*}{ 温 } & \multicolumn{2}{|c|}{ 総消費量 } & \multicolumn{3}{|c|}{1 昨間当り } & \multicolumn{3}{|c|}{ 茶 $10 \mathrm{~kg}$ 当り } \\
\hline & & & & & & 燃 料| & 金 額 & 燃料 & 金額 & 比率 & 燃料 & 金額 & 比率 \\
\hline $\begin{array}{c}\text { 年 } \text { 月 } \\
32.11 \\
\text { " }\end{array}$ & $\begin{array}{l}\text { 算2 } 2 \text { 区 } \\
\text { 第3 }\end{array}$ & $\begin{array}{l}\quad \min \\
1,428 \\
1,410\end{array}$ & $\begin{array}{r}\mathrm{kg} \\
4.522 \\
4.502\end{array}$ & $\begin{array}{r}\mathrm{kg} \\
1.156 \\
1.228\end{array}$ & $\begin{array}{r}{ }^{\circ} \mathbf{C}_{1} \\
56.7 \\
56.3\end{array}$ & $\begin{array}{r}\mathrm{kg} \\
5.379 \\
5.875\end{array}$ & $\begin{array}{l}376.55 \\
411.28\end{array}$ & $\begin{array}{r}\mathrm{kg} \\
0.226 \\
0.250\end{array}$ & $\begin{array}{r}7 \\
15.81 \\
17.50\end{array}$ & & $\begin{array}{r}\mathrm{kg} \\
0.521 \\
0.573\end{array}$ & $\begin{array}{r}\text { म丁. } \\
36.50 \\
40.08\end{array}$ & \\
\hline $\begin{array}{l}33.5 \\
\text { "I" " } \\
\text { "I }\end{array}$ & 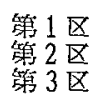 & $\begin{array}{r}742 \\
1,785 \\
1.785\end{array}$ & $\begin{array}{l}4.463 \\
4.497 \\
4.530\end{array}$ & $\begin{array}{l}1.139 \\
1.267 \\
1.228\end{array}$ & $\begin{array}{l}55.3 \\
54.2 \\
54.5\end{array}$ & $\begin{array}{l}6.876 \\
6.813 \\
6.931\end{array}$ & $\begin{array}{l}160.21 \\
476.93 \\
485.18\end{array}$ & $\begin{array}{l}0.556 \\
0.229 \\
0.233\end{array}$ & $\begin{array}{l}12.99 \\
16.03 \\
16.31\end{array}$ & $\begin{array}{l}100 \\
124 \\
126\end{array}$ & $\begin{array}{l}1.236 \\
0.509 \\
0.512\end{array}$ & & $\begin{array}{l}10 \\
12\end{array}$ \\
\hline 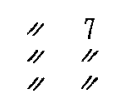 & $\begin{array}{l}\text { 第 } 1 \frac{1}{\text { 第 }} \\
\text { 第2 } \\
\text { 第3 }\end{array}$ & $\begin{array}{l}1,260 \\
1,260 \\
1,250\end{array}$ & $\begin{array}{l}3.872 \\
3.749 \\
3.753\end{array}$ & $\begin{array}{l}1.083 \\
1.062 \\
1.097\end{array}$ & $\begin{array}{l}55.4 \\
54.5 \\
55.0\end{array}$ & $\begin{array}{r}10.521 \\
4.263 \\
4.370\end{array}$ & $\begin{array}{l}245.14 \\
298.41 \\
305.90\end{array}$ & $\begin{array}{l}0.501 \\
0.203 \\
0.209\end{array}$ & $\begin{array}{l}11.69 \\
14.21 \\
14.89\end{array}$ & $\begin{array}{l}100 \\
122 \\
127\end{array}$ & $\begin{array}{l}1.292 \\
0.547 \\
0.551\end{array}$ & $\begin{array}{l}30.10 \\
38.30 \\
38.60\end{array}$ & \\
\hline 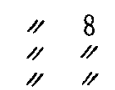 & 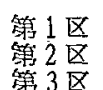 & $\begin{array}{l}410 \\
690 \\
679\end{array}$ & $\begin{array}{l}4.980 \\
4.750 \\
4.812\end{array}$ & $\begin{array}{l}1.329 \\
1.242 \\
1.380\end{array}$ & $\begin{array}{l}55.4 \\
51.7 \\
53.5\end{array}$ & $\begin{array}{l}3.513 \\
2.484 \\
2.580\end{array}$ & $\begin{array}{r}81.84 \\
173.88 \\
180.60\end{array}$ & $\begin{array}{l}0.514 \\
0.216 \\
0.228\end{array}$ & $\begin{array}{l}12.00 \\
15.12 \\
15.89\end{array}$ & $\begin{array}{l}100 \\
1.26 \\
132\end{array}$ & $\begin{array}{l}1.223 \\
0.5509 \\
0.514\end{array}$ & $\begin{array}{l}28.50 \\
35.60 \\
36.00\end{array}$ & \\
\hline
\end{tabular}

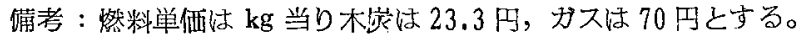

(3) 茶 の品賈

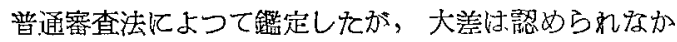
$\partial \tau_{0}$

（4）かま底声よび搡艋上の温度調查

かま底打よび揉盤の温度分布を，木宸とオ゙スにうき， 第 1 图のような測定位置について，揉盤を取り除いた場 合と，取り付けて製茶状態にした時とについて調査した 結果は策6 表に示した。
第 1 図

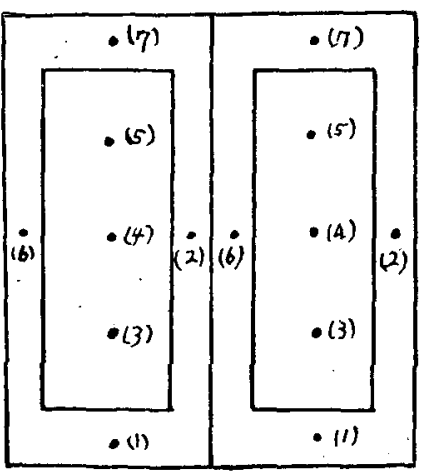

前 唰 


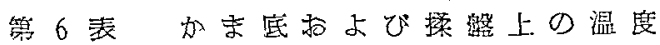

\begin{tabular}{|c|c|c|c|c|c|c|c|}
\hline \multirow{2}{*}{ 左右 } & \multirow{2}{*}{$\underbrace{\text { 置 }}_{\text {濝定位盤 }}$} & \multicolumn{2}{|c|}{1} & \multicolumn{2}{|c|}{2} & \multicolumn{2}{|c|}{3} \\
\hline & & なしの場合 & 取付けた場合 & なしの場合 & 取付敌灭㙷合 & なしの埸合 & 取付的て場合 \\
\hline 右 & $\begin{array}{l}1 \\
2 \\
3 \\
4 \\
5 \\
6 \\
7\end{array}$ & $\begin{array}{c}85.9 \mathrm{C} \\
168.0 \\
129.0 \\
167.0 \\
127.0 \\
176.0 \\
72.5\end{array}$ & $\begin{array}{c}61.0 \\
60 \\
168.7 \\
68.7 \\
73.8 \\
60.4 \\
166.0 \\
60.7\end{array}$ & $\begin{array}{c}35.4 \\
315 \\
115.0 \\
112.0 \\
169.0 \\
121.0 \\
121.0 \\
47.0\end{array}$ & $\begin{array}{c}33.0 \\
3.0 \\
115.0 \\
77.0 \\
90.0 \\
80.0 \\
123.0 \\
40.0\end{array}$ & $\begin{array}{l}61.5 \\
6{ }^{\circ} \mathrm{C} \\
165.0 \\
108.0 \\
163.0 \\
108.0 \\
162.0 \\
53.0\end{array}$ & $\begin{array}{c}50 .{ }^{\circ} \mathrm{C} \\
166.0 \\
75.0 \\
103.0 \\
76.0 \\
154.0 \\
49.0\end{array}$ \\
\hline 左 & $\begin{array}{l}1 \\
2 \\
3 \\
4 \\
5 \\
6 \\
7\end{array}$ & $\begin{array}{r}72.2 \\
167.0 \\
125.2 \\
166.0 \\
120.0 \\
161.0 \\
68.5\end{array}$ & $\begin{array}{r}69.4 . \\
163.4 \\
83.6 \\
91.2 \\
78.7 \\
151.5 \\
57.3\end{array}$ & $\begin{array}{r}34.0 \\
120.0 \\
106.0 \\
190.0 \\
128.6 \\
112.0 \\
49.0\end{array}$ & $\begin{array}{r}33.0 \\
118.0 \\
76.0 \\
92.7 \\
82.7 \\
114.0 \\
49.0\end{array}$ & $\begin{array}{r}49.0 \\
164.0 \\
113.0 \\
165.0 \\
114.0 \\
175.0 \\
53.0\end{array}$ & $\begin{array}{r}44.0 \\
180.0 \\
76.0 \\
96.0 \\
77.0 \\
190.0 \\
55.0\end{array}$ \\
\hline 左石平均 & $\begin{array}{l}1 \\
2 \\
3 \\
4 \\
5 \\
6 \\
7\end{array}$ & $\begin{array}{r}79.0 \\
167.5 \\
127.0 \\
166.5 \\
123.5 \\
168.0 \\
70.5\end{array}$ & $\begin{array}{r}65.0 \\
166.0 \\
76.0 \\
82.0 \\
70.0 \\
159.0 \\
59.0\end{array}$ & $\begin{array}{r}34.7 \\
117.5 \\
109.0 \\
180.0 \\
124.8 \\
116.0 \\
48.0\end{array}$ & $\begin{array}{r}33.0 \\
116.5 \\
76.5 \\
91.4 \\
81.3 \\
118.5 \\
44.5\end{array}$ & $\begin{array}{r}55.0 \\
164.5 \\
110.5 \\
164.0 \\
111.0 \\
168.0 \\
53.0\end{array}$ & $\begin{array}{r}47.0 \\
173.0 \\
75.0 \\
99.0 \\
76.0 \\
175.0 \\
52.0\end{array}$ \\
\hline
\end{tabular}

(5) 燃焼效率試験

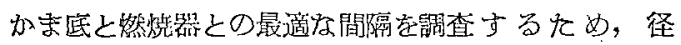
$29 \mathrm{~cm}$, 深さ $13 \mathrm{~cm}$ の蒸発なへ代 $3 \mathrm{~kg}$ の水を入れ, 一徍

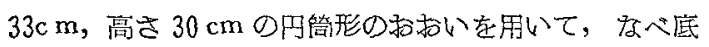

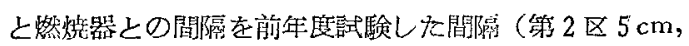

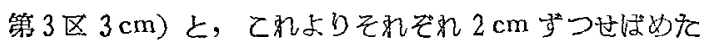
ものとについて胉榃した。測定は水の温度が上秏して最

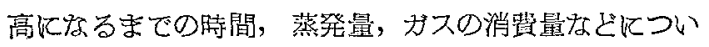
て行つたが，その結楽は第 7 表のようでする。ね效率 は次の式によつて算出した。

$$
\begin{aligned}
& \eta=\frac{M_{1}\left(t_{1}-t_{2}\right)+r M_{2}}{H m} \\
& \eta \text { 効 流 (\%) } \\
& \text { H カ3スの発熱量 }(11800 \mathrm{kcal} / \mathrm{kg}) \\
& \mathrm{m} \text { ガスの使用䱋 }(\mathrm{kg}) \\
& \mathrm{M}_{1} \text { 毁初の水量 }(\mathrm{kg}) \\
& \mathbf{t}_{1} \text { 蒛発中の水温 }\left({ }^{\circ} \mathrm{C}\right) \\
& \mathrm{t}_{2} \text { 最初 } 0 \text { 水温 }\left({ }^{\circ} \mathrm{C}\right)
\end{aligned}
$$

\begin{tabular}{|c|c|c|c|c|c|c|c|c|c|c|c|c|}
\hline \multirow{2}{*}{ 区 } & & \multirow{2}{*}{ 別 } & \multirow{2}{*}{ 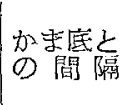 } & \multirow{2}{*}{ 試験時間 } & \multicolumn{2}{|c|}{ 窒内温度 } & \multirow{2}{*}{$\begin{array}{l}\text { 鼠物 } \\
\text { 水 湿 }\end{array}$} & \multirow{2}{*}{ 熱発量 } & \multirow{2}{*}{ 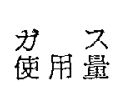 } & \multirow{2}{*}{ 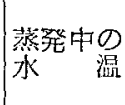 } & \multirow{2}{*}{$\mid \begin{array}{l}\text { 最高沈な } \\
\text { るまでの } \\
\text { 時 }\end{array}$} & \multirow{2}{*}{ 效 率 } \\
\hline & & & & & 乾 球 & 湿 球 & & & & & & \\
\hline \multirow[t]{2}{*}{ 第 } & 2 & 区 & $5^{\mathrm{cm}}$ & $\min _{142}$ & $13 .{ }^{\circ} \mathrm{C}$ & $\begin{array}{l}{ }^{\circ} \mathrm{C} \\
10.8\end{array}$ & 11.1 & 1.546 & $0.227^{\mathrm{kg}}$ & $78 .{ }^{\circ} \mathrm{C}$ & $\min _{47}$ & $39.6^{\circ}$ \\
\hline & "I & & 3 & 120 & 9.9 & 8.0 & 8.5 & 2.000 & 0.234 & 81.9 & 39 & 47.8 \\
\hline \multirow[t]{2}{*}{ 第 } & 3 & $区$ & 3 & 124 & 13.5 & 10.8 & 10.8 . & 1.047 & 0.234 & 72.5 & 54 & 27.8 \\
\hline & $" 1$ & & 1 & 120 & 9.9 & 8.0 & 8.3 & 1.332 & 0.234 & 74.0 & 50 & 33.9 \\
\hline
\end{tabular}

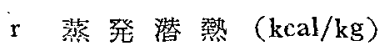

$$
\begin{aligned}
& \mathrm{M}_{2} \text { 蒸発水量 }(\mathrm{kg})
\end{aligned}
$$

第 7 㝨 效 率試 験 結 果

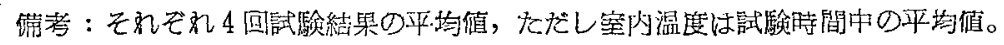

(6) 火瓷の政良についての調査

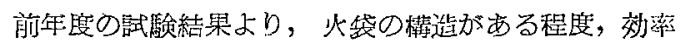

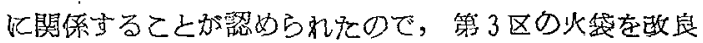
したところ，ガスの消費量を11\%队外節減するこよがで きた。

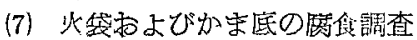

一番茶 190 洔間, 二番茶 160 時間, 三番茶 110 㭙間, 四番茶60蛙間，計 520 時間使用した結果，木炭を用いた ஆのに比校して，カスを使用したものは，かま底の應食
がある程度多かつた。

(8) 摘 㜖

（a） 1 回の精揉時間は約33分で，慜茶能率は，時間当

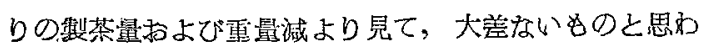
れるが，経闵的にはガスは木㟶比比べて，25\%内外経費 を多く要す尚ようである。

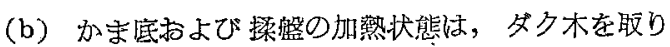
はずして調查した結果，第 2 区慓準区化比較して，中 央部が特偪く，2，40位置は $40^{\circ} \mathrm{C}$ 内外，その他の 


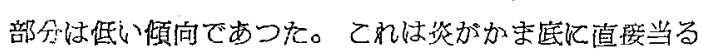
ので，中央部の简部的炕過熱されるからで，乙のため かま底拉よび揉盤のダク林が 過熱のため損賃を起し易

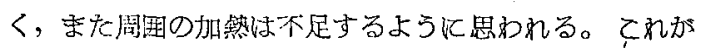

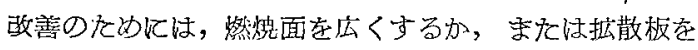

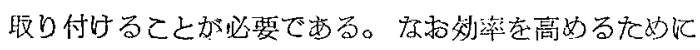

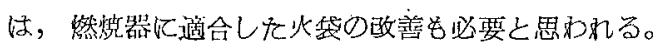

(c) 第 3 区はその点，燃烧器の上部汇资を抁散する

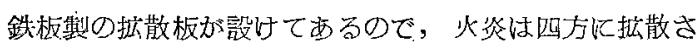

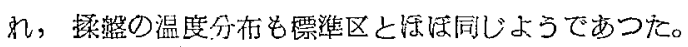
しかしてのようにすると，加ま底の損筑は少いが，熱効 率が多少低下するので，效率を良くするためには，搪薢 板を故熱効果の良いものとし，さらにその構造を敳善す るとと病どの研究が必要と思放る。

\section{3 静同県茶業試験場}

(1) 万法

試験は各茶期とも，4号粗揉譏を用い（投入量は

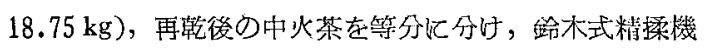

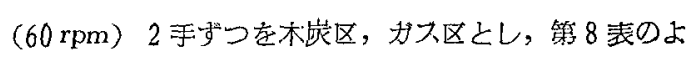
うな区別炕より行つた。

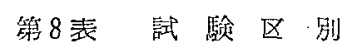

\begin{tabular}{|c|c|c|c|}
\hline 区 別 & 然 蝳 㗊 & 燃 料 & 跸 \\
\hline 第 $1 区$ & 雃来のと拾り & 木宸 & 鈴氺式は岩谷産 \\
\hline 第 2 区 & 第 1 プロパン式 & $\ddot{ス}$ ス & 業式と同じ。 \\
\hline 第3区 & 铪 木 式 & $" 1$ & \\
\hline
\end{tabular}

（2）筫試原料

供試原料は当場はさみ摘生䒚を用い，試殷月日は次の とおりで要。

一番茶：5月18日, 19日, 20日

二潘茶：6月28日，29日，30日，7月1日，4日，5日 三番茶：8月8日，11日

(3) 燃料消貲量

燃料の消費量和よびその金額などは，第 9 表のと枋り である。

第 9 表 縩料消貲量

\begin{tabular}{|c|c|c|c|c|c|c|c|c|c|c|}
\hline \multirow{2}{*}{ 茶 } & \multirow{2}{*}{ 区 } & \multirow{2}{*}{ 別 } & \multirow{2}{*}{ 調查回数 } & \multirow{2}{*}{ 青国当り } & \multicolumn{3}{|c|}{1 間当り消費量 } & \multicolumn{3}{|c|}{ 茶 $10 \mathrm{~kg}$ 当り消䫍量 } \\
\hline & & & & & 縩 料 & 金 額 & 比率 & 燃 䊀 & 金 額 & 比率 \\
\hline 一雷菜 & 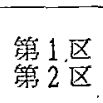 & 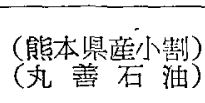 & $\begin{array}{l}29^{\text {回 }} \\
29^{2}\end{array}$ & $\begin{array}{l}3^{\min } \\
37\end{array}$ & $\begin{array}{l}\quad \mathrm{kg} \\
0.449 \\
0.219\end{array}$ & $\begin{array}{l}19 \\
10.49 \\
14.24\end{array}$ & $\begin{array}{l}100 \\
136\end{array}$ & $\begin{array}{l}\mathrm{kg} \\
1.200 \\
0.560\end{array}$ & $\begin{array}{l}\text { P } \\
28.00 \\
36.00\end{array}$ & $\begin{array}{l}100 \\
130\end{array}$ \\
\hline 二番茶 & $\begin{array}{l}\text { 第1 } 1 \text { 区 } \\
\text { 第2 } \\
\text { 第3区 }\end{array}$ & 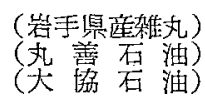 & $\begin{array}{l}37 \\
37 \\
30\end{array}$ & $\begin{array}{l}33 \\
33 \\
31\end{array}$ & $\begin{array}{l}0.500 \\
0.223 \\
0.200\end{array}$ & $\begin{array}{l}11.66 \\
14.50 \\
13.00\end{array}$ & $\begin{array}{l}100 \\
124 \\
1.11\end{array}$ & $\begin{array}{l}1.150 \\
0.510 \\
0.431\end{array}$ & $\begin{array}{l}26.83 \\
33.15 \\
28.02\end{array}$ & $\begin{array}{l}100 \\
124 \\
104\end{array}$ \\
\hline 三番茶 & 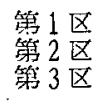 & 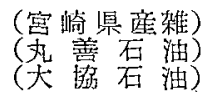 & $\begin{array}{l}20 \\
20 \\
20\end{array}$ & $\begin{array}{l}34 \\
34 \\
34\end{array}$ & $\begin{array}{l}0.498 \\
0.220 \\
0.210\end{array}$ & $\begin{array}{l}11.60 \\
14.30 \\
13.65\end{array}$ & $\begin{array}{l}100 \\
123 \\
118\end{array}$ & $\begin{array}{l}1.244 \\
0.540 \\
0.517\end{array}$ & $\begin{array}{l}29.01 \\
35.23 \\
33.61\end{array}$ & $\begin{array}{l}100 \\
121 \\
116\end{array}$ \\
\hline
\end{tabular}

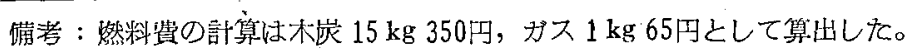

（4）精揉機の揉盤温度と火袋の表面温度

第 2 図炕示す位置で測定した揉盤各部の温度は 第10表 のと括りで，また第了图比火笺の前側の表面温度学測定 した結果を示した。
（5）精揉機の火赀和よびかま底の筑食度

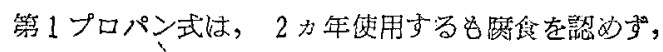

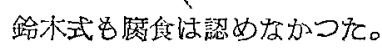

第 10 表 温

度

\begin{tabular}{|c|c|c|c|c|c|c|c|c|c|}
\hline \multirow{2}{*}{ 測定位置 } & \multicolumn{3}{|c|}{ 前 部 } & \multicolumn{3}{|c|}{ 中 央 部 } & \multicolumn{3}{|c|}{ 後部 } \\
\hline & 対 照 & |第ロパン式 & 鉿木式 & 奶 照 & 第ロパン式 & 鉿林式 & 奶 照 & 霉ロパン式 & 路机式 \\
\hline 1 & ${ }_{108}^{\circ} \mathrm{C}$ & $101^{\circ} \mathrm{C}$ & $92^{\circ} \mathrm{C}$ & ${ }_{146}^{\circ} \mathrm{C}$ & $110^{\circ}$ & $113^{\circ} \mathrm{C}$ & ${ }_{108^{\circ}} \mathrm{C}$ & $86^{\circ} \mathrm{C}$ & $91^{\circ} \mathrm{C}$ \\
\hline 2 & 75 & 72 & 57 & 99 & 66 & 75 & 68 & 66 & 58 \\
\hline 3 & 115 & 100 & 98 & 144 & 123 & 121 & 108 & 93 & 87 \\
\hline 4 & 100 & $96^{\circ}$ & 77 & 154 & 116 & 115 & 103 & 85 & 81 \\
\hline 5 & 79 & 77 & 55 & 97 & 64 & 74 & 88 & 73 & 56 \\
\hline 6 & 116 & 97 & 98 & 164 & 103 & 115 & 100 & 91 & 93 \\
\hline
\end{tabular}

诵洘：測定時の室温注 $29^{\circ} \mathrm{C}$ 


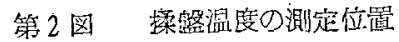

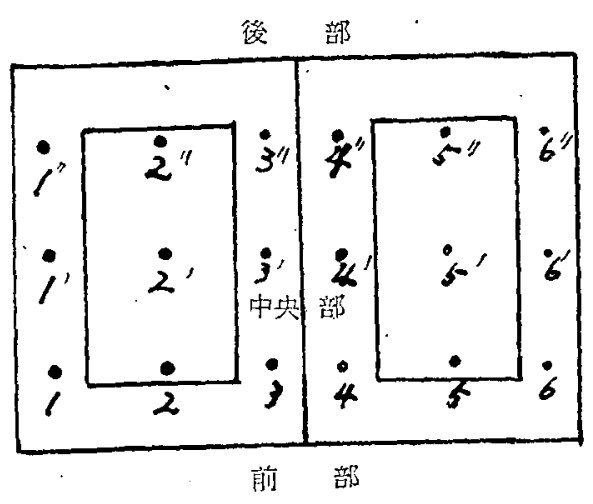

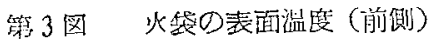

$118^{\circ} \mathrm{C} \quad 104^{\circ} \mathrm{C} \quad 120 \mathrm{C} \quad 92^{\circ} \mathrm{C} \quad 85^{\circ} \mathrm{C} \quad 87^{\circ} \mathrm{C}$

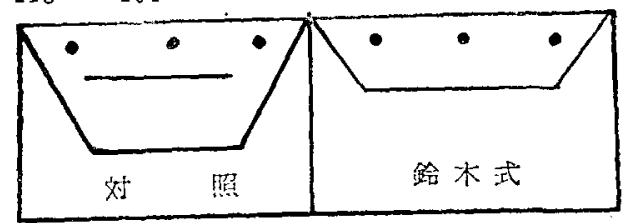

(6) 茶の奛質

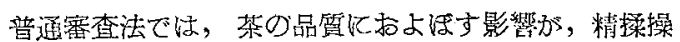
作によるものか，撚料の種別拘よび給熱方法化よるもの か判然としなかつた。

\section{4 三重県農業試験場茶業分場}

(1) 万法和よび饲験区別

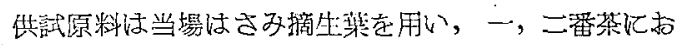
いて試験した。

供試精搡機は八木式和よび 惄田式と蜘炶器ならびに， 蜘料は第11素のと永りである。

第 11 表 試 歌区 別

\begin{tabular}{|c|c|c|c|}
\hline 区 別 & 燃 焼 器 & 料 & 洘 \\
\hline 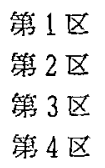 & 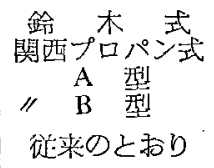 & $\begin{array}{c}\text { 丹开 } \\
\text { 大協ガス } \\
\text { " } \\
\text { ホ宸 }\end{array}$ & $\begin{array}{l}\text { ホンンベは } 50 \mathrm{~kg} \\
\text { 入りをを使用し } \\
\text { た。 }\end{array}$ \\
\hline
\end{tabular}

(2) 然料消費量

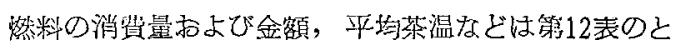
おりである。

第 12 表 然 料 消 費 量

\begin{tabular}{|c|c|c|c|c|c|c|c|c|c|c|c|c|}
\hline \multirow{2}{*}{ 茶期 } & \multirow{2}{*}{ 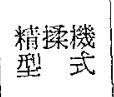 } & \multirow{2}{*}{ 繠烧器犁试 } & \multirow{2}{*}{\multicolumn{2}{|c|}{ 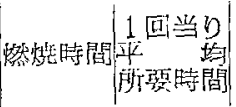 }} & \multirow{2}{*}{ 聖壹减 } & \multirow{2}{*}{ 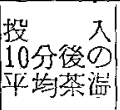 } & \multicolumn{3}{|c|}{1 時間当口消費量 } & \multicolumn{3}{|c|}{ 茶 $10 \mathrm{~kg}$ 当口消費量 } \\
\hline & & & & & & & 然 料 & 金 額 & 比率 & 然 料 & 金 額 & 比率 \\
\hline \multirow{5}{*}{ 一粱茶 } & \multirow{3}{*}{ 八不式 } & \multirow{2}{*}{$\begin{array}{l}\text { 鉿 } \text { 式 } \\
\text { 木 崖 }\end{array}$} & $\begin{array}{r}\min \\
1,393\end{array}$ & $2^{\min }$ & $18.0^{\%}$ & 50 & $\begin{array}{c}\mathrm{kg} \\
0.312\end{array}$ & 21.85 & \multirow{2}{*}{$\begin{array}{l}161 \\
100\end{array}$} & $\begin{array}{r}\mathrm{kg} \\
0.590\end{array}$ & $41.32^{\bar{J}}$ & \multirow{2}{*}{$\begin{array}{l}164 \\
100\end{array}$} \\
\hline & & & 1,417 & 27 & 16.7 & 50 & 0.594 & 13.65 & & 1.098 & 25.24 & \\
\hline & & \multirow{3}{*}{ 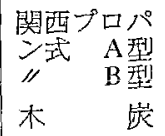 } & 444 & 29 & 17.8 & 50 & \multirow{3}{*}{$\begin{array}{l}0.172 \\
0.249 \\
0.754\end{array}$} & 12.04 & \multirow{3}{*}{$\begin{array}{r}69 \\
101 \\
100\end{array}$} & 0.350 & \multicolumn{2}{|l|}{24.50} \\
\hline & \multirow{2}{*}{ 寺田式 } & & 385 & 36 & 19.6 & 51 & & 17.46 & & 0.566 & 39.61 & 118 \\
\hline & & & 797 & 29 & 18.9 & 50 & & 17.34 & & 1.463 & 33.65 & 100 \\
\hline & & 踰杢式 & 1.014 & 33 & 20.2 & 50 & 0.261 & 18.22 & 106 & 0.554 & 38.74 & 128 \\
\hline & 木式了 & & 1,014 & 28 & 21.5 & 51 & 0.744 & 17.11 & 100 & 1.316 & 30.27 & 100 \\
\hline 二番茶 & & 闗西ナロパ & 500 & 33 & 23.1 & 50 & 0.276 & 19.32 & 109 & 0.603 & 42.18 & 119 \\
\hline & 寺田式 & " I $\mathrm{B}$ 型 & 572 & 32 & 23.3 & 51 & 0.231 & 16.16 & 92 & 0.485 & 33.96 & 96 \\
\hline & & 木 炭 & 960 & 31 & 19.0 & 51 & 0.788 & 17.66 & 100 & 1.543 & 35.49 & 100 \\
\hline
\end{tabular}

碏洘：燃料単伯は $\mathrm{kg}$ 当り木炭は 23 円，ガスは 70 円とする。

(3) 茶 $の$ 品磒

茶の品質は，外観・内容之もに䅺準に比较して差異は 胃られなかつた。

(4) 摘 要

使用の聥否は不慣れの点も多かつたが，ガスは校に 比较して消望量が多く，制品 $10 \mathrm{~kg}$ 当りの燃料貲は高く

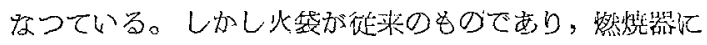
適さないてとを考えると，乙礼の政良沉よつて柏当の熱 効率を上げるととができるものと思的れる。また火垬の

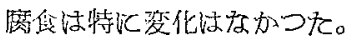

\section{5 京都府茶業研究所}

(1) 方 法

縩料和よび供試精势機注，ツバメブタンガスは八木 式，木炭は寺田式の各 3 手を用い，漈燒器の構造は鋳鉄 䑾ドーナツ型である。

(2) 燃料消費量

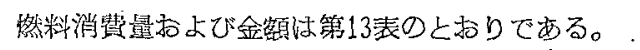


第 13 表蜘 料消頃 量

\begin{tabular}{|c|c|c|c|c|c|c|c|c|c|c|c|c|c|}
\hline \multirow{2}{*}{$\begin{array}{l}\text { 碔験 } \\
\text { 月昌 }\end{array}$} & \multirow{2}{*}{ 区別 } & \multirow{2}{*}{ 試験時間 } & \multirow{2}{*}{ 製茶量 } & \multirow{2}{*}{$\begin{array}{l}1 \text { 回业 } \\
\text { 所要時間 }\end{array}$} & \multicolumn{3}{|c|}{ 総消貿量 } & \multicolumn{3}{|c|}{1 㭙間当り消費量 } & \multicolumn{3}{|c|}{ 茶 $10 \mathrm{~kg}$ 当口消費量 } \\
\hline & & & & & 然 料 & 金 䂓 & 比率 & 聮 料 & 金 額 & 比率 & 㜣 料 & 金 額 & 比率 \\
\hline 5.13 & プタン & $\begin{array}{l}\min \\
585\end{array}$ & $\begin{array}{r}\mathrm{kg} \\
51.86\end{array}$ & $\begin{array}{c}\operatorname{mil} \\
39\end{array}$ & 3.200 & $224.00^{\text {P }}$ & 109 & $\begin{array}{r}\mathrm{kg} \\
0.328\end{array}$ & 22.96 & 104 & $\begin{array}{r}\mathrm{kg} \\
0.617\end{array}$ & 43.19 & 108 \\
\hline$"$ & 木 炭 & 557 & 51.12 & 37 & 7.690 & 205.09 & 100 & 0.829 & 22.10 & 100 & 1.504 & 40.10 & 100 \\
\hline 14 & プタン & 721 & 64.66 & 38 & 3.600 & 252.00 & 91 & 0.299 & 20.95 & 96 & 0.557 & 39.99 & 98 \\
\hline$"$ & 朴炭 & 765 & 68.06 & 38 & 10.400 & 277.37 & 100 & 0.816 & 21.76 & 100 & 1.528 & 40.75 & 100 \\
\hline 15 & ブタン & 480 & 37.51 & 44 & 2.700 & 189.00 & - & 0.358 & 23.66 & - & 0.720 & 50.40 & - \\
\hline
\end{tabular}

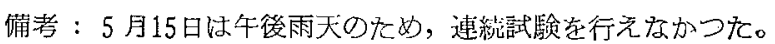

然料単価は $\mathrm{kg}$ 当り木炭は 26.67 円，ブタンガスは 70 円上守る。

(3) 摘 要

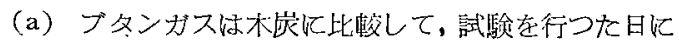
よつて高低㹸あつたが，大体同じくらいの貿周であつ

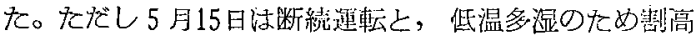
であつた。

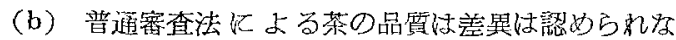
かつたが，ブタンガスは労力節堿と調節自由のため制 品にむら加外く，獎尉できると思う。

（c）精揉機の火袋打よびかま底の陵食は異状を㒛めな かつた。

\section{6 奈良県農業試験場茶業分場}

(1) 方 法

䟕烧器はツバメプロパン式, 燃料はツバメプロパンガ 又和よび木炭 (栖中細)，供試精揉機は八木式 4 手（31年 型）により，一，二番茶の中期のはさみ摘葉を用いて行 つた。な和精揉操作は每回の中火茶を二分してそれぞれ 平均江入した。

(2) 然料消費最

燃料の消蛽量和よび金額は第14表のとおりである。

第 14 表 撚。料消費量

\begin{tabular}{|c|c|c|c|c|c|c|c|c|c|c|c|c|c|c|}
\hline \multirow{2}{*}{$\begin{array}{l}\text { 試験 } \\
\text { 量日 }\end{array}$} & 区 & \multirow{2}{*}{$\begin{array}{l}\text { 詿驗 } \\
\text { 時鿶 }\end{array}$} & \multirow{2}{*}{ 回数 } & \multirow{2}{*}{ 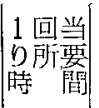 } & \multirow{2}{*}{ 製茶量 } & \multicolumn{3}{|c|}{ 総消費 量 } & \multicolumn{3}{|c|}{1 時間当り消費量 } & \multicolumn{3}{|c|}{ 茶 $10 \mathrm{~kg}$ 当口消凅易 } \\
\hline & 別 & & & & & 燃 料 | & 金 額 & 比率 & 燃料 & 金額 & 比湤 & 撚料 & 金額 & 比率 \\
\hline \multirow{2}{*}{5.25} & プロパンダス & $\begin{array}{c}\min \\
500\end{array}$ & 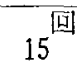 & $\begin{array}{l}\min \\
31\end{array}$ & $\begin{array}{r}\mathrm{kg} \\
28.050\end{array}$ & $\begin{array}{r}\mathrm{kg} \\
1.820\end{array}$ & $\begin{array}{r}\mathrm{⿴囗十} \\
118.30\end{array}$ & 117 & $\begin{array}{r}\mathrm{kg} \\
0.218\end{array}$ & $\begin{array}{r}\text { PT } \\
14.17\end{array}$ & 117 & $\begin{array}{r}\mathrm{kg} \\
0.648\end{array}$ & 44.12 & 128 \\
\hline & 孷 & 500 & 15 & 32 & 29.410 & 5.062 & 101.24 & 100 & 0.607 & 12.14 & 100 & 1.721 & 34.42 & 100 \\
\hline \multirow{2}{*}{7.10} & プロパンガス & 510 & 14 & 35 & 28.800 & 1.680 & 109.20 & $\cdot 115$ & 0.198 & 12.81 & 114 & 0.559 & 38.93 & 120 \\
\hline & 木 & 510 & 14 & 34 & 29,210 & 4.774 & 94.94 & 100 & 0.557 & 11.16 & 100 & 1.613 & 32.26 & 10 \\
\hline
\end{tabular}

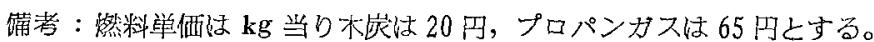

(3) 菜の品質

一，二番茶とも品質差は諗められなかつた。

(4) 腐 的 度

火垡怙よびかま底の腐食は差がなかつた。

(5) 摘 要

（a）精揉特間は一，二番葉とも河とんど差がなかつ tco

（b）然料贊は，ブパンガスはホ炭に比較して㭙間 当り $16.7 \sim 14.8 \%$ ，製品 $10 \mathrm{~kg}$ 当りで28.0〜20.6\%，て れぞれ経費を多く要した。 （c）プロパンガスは温莨の調節あるいは点火，消火な ぞ非常汇便利である。

\section{7 九州農業試験場作物第 1 部}

(1) 方 法

精媃機は八木式 2 手を用い，火袋はそのままで，燃焼 器をかま底から $3 \mathrm{~cm}$ 離しボルトで取り付けた。な的然 炶器の式名, 性能は不明でする。

(2) 縩料消費量

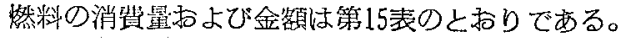




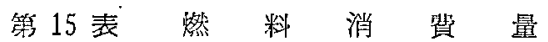

\begin{tabular}{|c|c|c|c|c|c|c|c|c|c|c|c|}
\hline \multirow{2}{*}{ 茶 } & \multirow{2}{*}{ 試験月日 } & \multirow{2}{*}{$区$} & \multirow{2}{*}{ 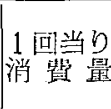 } & \multirow{2}{*}{ 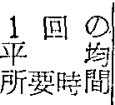 } & \multirow{2}{*}{ 使用前の } & \multicolumn{3}{|c|}{1 時間当り消賢㬈 } & \multicolumn{3}{|c|}{ 茶 $10 \mathrm{~kg}$ 当口浮貲量 } \\
\hline & & & & & & 燃 料 & 金 額 & 比 摔 & 然 檥 & 金 額 & 比 摔 \\
\hline 一潘茶 & $5.17\}$ & 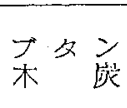 & $\begin{array}{r}\mathrm{g} \\
100^{-} \\
417\end{array}$ & $\begin{array}{l}\text { min } \\
31 \\
30\end{array}$ & $\begin{array}{r}{ }^{\circ} \mathrm{C} \\
89.5 \\
90.0\end{array}$ & $\begin{array}{l}\quad \mathrm{kg} \\
0.1 .92 \\
0.759\end{array}$ & $\begin{array}{l}\text { 円 } \\
10.49 \\
13.36\end{array}$ & $\begin{array}{r}82 \\
100\end{array}$ & $\begin{array}{l}\mathrm{kg} \\
0.455 \\
1.890\end{array}$ & $\begin{array}{r}\text { P } \\
25.94 \\
33.45\end{array}$ & $\begin{array}{r}78 \\
100\end{array}$ \\
\hline 二番茶 & $6.28\}$ & 杀多㑞 & $\begin{array}{l}133 \\
475\end{array}$ & $\begin{array}{l}34 \\
35\end{array}$ & $\begin{array}{l}112.0 \\
116.0\end{array}$ & $\begin{array}{l}0.243 \\
0.816\end{array}$ & $\begin{array}{l}13.85 \\
14.44\end{array}$ & $\begin{array}{r}96 \\
100\end{array}$ & $\begin{array}{l}0.539 \\
1.940\end{array}$ & $\begin{array}{l}30.70 \\
34.40\end{array}$ & $\begin{array}{r}89 \\
100\end{array}$ \\
\hline 三番茶 & 8.8\{ & 杂々炭 & $\begin{array}{l}139 \\
394\end{array}$ & $\begin{array}{l}31 \\
31\end{array}$ & $\begin{array}{l}108.0 \\
103.0\end{array}$ & $\begin{array}{l}0.268 \\
0.759\end{array}$ & $\begin{array}{l}15.29 \\
13.43\end{array}$ & $\begin{array}{l}114 \\
100\end{array}$ & $\begin{array}{l}0.603 \\
1.710\end{array}$ & $\begin{array}{l}34.30 \\
30.30\end{array}$ & $\begin{array}{l}113 \\
100\end{array}$ \\
\hline
\end{tabular}

确考：然料単価は $\mathrm{kg}$ 当り木炭は 17.7 円,ブタンガスは 57 円とする。

(3) 茶の品質

いずれも㹕茶にはブタンガスの臭味は察うたくなく， 裴造上の盖の弫うが大きいようであるが，大差は㒛妨ら れなかつた。

(4) 摘 要

（a）然料消費量と然料費と口関俰证，製茶 $10 \mathrm{~kg}$ 当り では畏時間使用した場合はブタンガスが安く，木炭の练 うが高くなる。

（b）林底の腐促度は，㨏は恃とんど变化なく，ブ
タンガスは炎の海たる部分が白く酸化されているが，別 飞異状はない。火袋はいずれも変化ない。

\section{8 鹿児島県茶業試験場}

- (1) 方 法

一番茶に八木式精揉機 2 手を使用して木炭と比较し \%。

(2) 燃料消唄量

然料の消費量および金額好筫16表のとおりである。

第 16 表、然料，消費量

\begin{tabular}{|c|c|c|c|c|c|c|c|c|c|c|c|}
\hline \multirow{2}{*}{ 試験月日 } & \multirow{2}{*}{$区$} & \multirow{2}{*}{ 別 } & \multirow{2}{*}{ 投入回数 } & \multirow{2}{*}{ 試殹侴時間 } & \multicolumn{3}{|c|}{ 総 消 費 量 } & \multicolumn{3}{|c|}{1 時間当り消費量 } & \multirow{2}{*}{ 窒 混 } \\
\hline & & & & & 燃 料 & 金 額 & 比 溸 & 燃 料 & 金 額 & 比 率 & \\
\hline 5.20 & -゚ロ & $\begin{array}{l}\text { ンস্য } \\
\text { 荻 }\end{array}$ & $\begin{array}{l}17^{\text {可 }} \\
18\end{array}$ & $\begin{array}{l}\quad \text { min } \\
370 \\
394\end{array}$ & $\begin{array}{l}\quad \mathrm{kg} \\
2.360^{\mathrm{kg}} \\
6.400\end{array}$ & $\begin{array}{r}236.00 \\
94.00\end{array}$ & $\begin{array}{l}251 \\
100\end{array}$ & $\begin{array}{l}0.232^{\mathrm{kg}} \\
0.605\end{array}$ & $\begin{array}{c}23.20^{\mathrm{P}} \\
8.90\end{array}$ & $\begin{array}{l}261 \\
100\end{array}$ & 21.0 \\
\hline 5.22$\}$ & 욤모 & ンガス & $\begin{array}{l}23 \\
23\end{array}$ & $\begin{array}{l}395 \\
385\end{array}$ & $\begin{array}{l}2.160 \\
7.000\end{array}$ & $\begin{array}{l}216.00 \\
102.00\end{array}$ & $\begin{array}{l}212 \\
100\end{array}$ & $\begin{array}{l}0.204 \\
0.672\end{array}$ & $\begin{array}{r}20.40 \\
9.90\end{array}$ & $\begin{array}{l}206 \\
100\end{array}$ & 28.5 \\
\hline $5.23 \frac{1}{1}$ & プロי & $\begin{array}{l}\text { ンガス } \\
\text { 宸 }\end{array}$ & $\begin{array}{l}21 \\
20\end{array}$ & $\begin{array}{l}396 \\
372\end{array}$ & $\begin{array}{l}2.440 \\
5.400\end{array}$ & $\begin{array}{r}244.00 \\
79.00\end{array}$ & $\begin{array}{l}308 \\
100\end{array}$ & $\begin{array}{l}0.230 \\
0.529\end{array}$ & $\begin{array}{r}23.00 \\
7.80\end{array}$ & $\begin{array}{l}295 \\
100\end{array}$ & 21.0 \\
\hline 评均 \{ & $\begin{array}{c}\text { プロ } \\
\text { 木 }\end{array}$ & 将ス & - & $\begin{array}{l}387 \\
383\end{array}$ & $\begin{array}{l}2.320 \\
6.266\end{array}$ & $\begin{array}{r}2: 32.00 \\
91.00\end{array}$ & $\begin{array}{l}255 \\
100\end{array}$ & $\begin{array}{l}0.222 \\
0.602\end{array}$ & $\begin{array}{r}22.20 \\
8.80\end{array}$ & $\begin{array}{l}252 \\
100\end{array}$ & 23.5 \\
\hline
\end{tabular}

诵考：然料单洒仗 $\mathrm{kg}$ 当り木炭は 14.7 円，プロパンガスは 100 円とする。

(3) 茶の品筫

本䳝験中には盖は認められなかつた。

(4) 火袋市よびかま底の腐县度

観察によると，プロパンガスはかが底鉄板が灰白色に

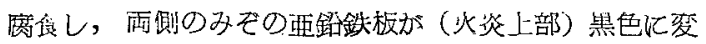
色し，木炭に比較して腐传度が目立つた。

(5) 摘 要

精揉機 4 手 1 台当りのプロパンデス消費量は，木㘸に

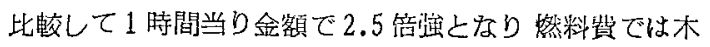
孷汇少つたが，取报いが非常に簡易で，平妇した火力の

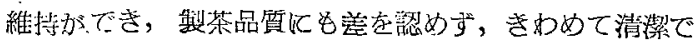
あつた。

すなわちての試験に使用したプロパンガスと恢の俩
額比では，経済的炕は木炭に遠く及ばないととがわかつ たがプロパンガスが安価になつた場合に拘いては，製 茶撚料として十分使用し得るものと認められる。

\section{4 総括}

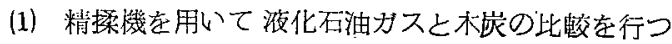
たが，襄造能率には大盖がなかつた。

（2）茶の品質は外観・内容ともに大差を謥めないが， 場所火よつてはガスを用いた潘うが品質が良好である場 合もあつた。これはガスのはうが労偊条件がよくなるた めであつて，ガスそのものの性望ではないと思われる。

(3）燃料の消哄量は場所化よつて異なり，またプロパ ンガスとブタンガスの㣫頑の遠いもあつて，特間当りの 
蜘焼量には相当の差がある。多い所は $300 \mathrm{~g}$ 以上，少い 所では $200 \mathrm{~g}$ 内外でその差は $100 \mathrm{~g}$ 以上ある。しかし2

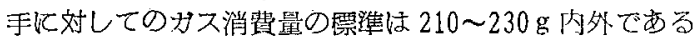
と推定される。

(4) 製品 $10 \mathrm{~kg}$ 当りでほ，荣の良否によつて精搮機の 所要時問が暴なるので，当然消費量にも恙があるが，経 济的炕はプロパンガスを吼いるより，ブタンガスを用い る㴽うがよい思われる。

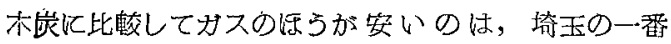
茶, 三重の一番茶，九州の一・番茶で，他惊いずれも

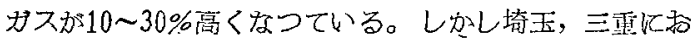
いても，然烧器の種頪によつては必ずしも木炭より有利 とは限らず，全体の結果よりみても燃烓器の椑造による 影響が大きいととがれかる。

(5) カス消唄量は然焼器の構造, 然料の種類によつて も黑なり，また対照化した木炭の炭質と価格によつて然 料貲の算出の基礎が異なるので一概炕はいえないが，木
崖の価格の高い地方で结経済的沉有利であるが，木医の 安い地方では割高となる。

(6) 石油液化ガスを凬いることは，作業の简易化，工 場内の清橴, 学働生阵性の向上などの点加らその意義は

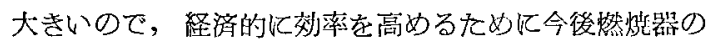
改善および，乙れに適する火裚の構造, 蜘䡒器とかま底 との間隔などの研究が必要亡思われる。

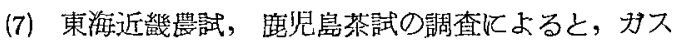

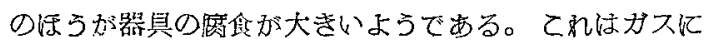
含まれる有害成分のためだけでなく，灼熱度が溞いた

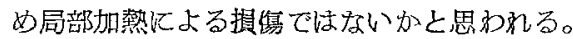

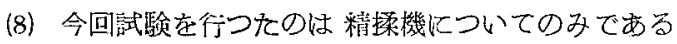

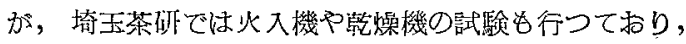
奏用化の可能性㛎るようである。ただし粗揉機，再乾 機等の熱風灭焒们用いるととはあまり期待できない。

(教茶第一研究堂記) 